\title{
Florin Topoleanu, Lămpile antice din colecţiile Muzeului Judeţean de Istorie şi arheologie Prahova - Ploiești, 264 p., XXII pl., Editura Oscar Print, București, 2012
}

Colecţiile muzeelor de istorie ascund încă multe piese necunoscute specialiștilor. Este şi cazul muzeului ploieştean, care în decursul timpului, în mod special în perioada de început a sa a achiziţionat un număr de 143 de lămpi.

Este foarte adevărat că din acest lot doar şase opaiţe au loc de descoperire cunoscut. Chiar şi aşa, iniţiativa lui Florin Topoleanu este vrednică de toată lauda, pentru că autorul încearcă, printre altele, să desluşească, acolo unde se poate, zona de provenienţă a unora dintre ele.

Colecţia cuprinde lucerne din epoca greacă secolele VII-I a. Chr. şi până în epoca medievală, în veacul al XIV-lea, dar cele mai multe piese sunt din epoca romană.

Prezentarea este fãcută, aşa cum era şi firesc, în ordine cronologică.

Primele lucerne analizate sunt cele greceşti, 12 la număr, între care cea mai vechie este o piesă cunoscută în literatura de specialitate sub numele de „feniciano-punic”. Este o piesă rară în România ce datează de la sfârşitul secolului al VII-lea a. Chr.

Restul opaiţelor din acest prim capitol sunt de origine elenistică, încadrându-se în mai multe tipuri, cele mai multe atice şi un tipar bival a cărui formă îl apropie de lucernele din Cipru din veacurile II-I a. Chr.

Un al doilea capitol este rezervat „opaif̧elor romane timpuri" ce sunt încadrate în răstimpul secolelor I a. Chr.-sec IV p. Chr. Este, fără îndoială, capitolul cel mai consistent. Primele exemplare sunt două opaiţe de epocă republicană şi ele forme foarte rar întâlnite pe teritoriul României. Autorul aminteşte ca singură analogie în zonă două lucerne de la Porolissum, din săpături mai vechi.

Un tip larg cunoscut în provinciile Moesia Inferioare şi Dacia este opaiţul cu volute. De altfel, trebuie să remarcăm şi faptul că împărţirea tipologică făcută de Florin Topoleanu lotului de lucerne de la Ploieşti este racordată la marile cataloage din imperiul roman şi ar fi de amintit aici doar cel al lui S. Loeschcke sau D. M. Bailey, fapt binevenit, care uşurează parcurgerea textului.

Următoarele două piese sunt din seria binecunoscutului producător Romanesis. Una dintre piese a fost descoperită la Callatis şi a făcut parte din colecţia George Severeanu.

Un lot important din colectie îl reprezintă opaiţele de tip Firma Lampere. „Popularitatea lor în toată lumea romană de-a lungul a peste trei secole, calitatea deosebită a produselor și prestigiul mărcilor de origine a determinat copierea sau imitarea lor în ateliere provinciale". Din colecţia ploieşteană o singură piesă este de tipul IX (după clasificarea lui Loeschcke), purtând ștampila Fortis, restul de 19 fiind de tipul următor. Aici se observă existenţa nu numai a unor ştampile clasice aparţinând unor meşteri din atelierele nord italice, dar şi prezenţa unor nume ca Armenius sau Flavius, meşteri care au funcţionat în zonă şi deci lucernele cu ştampila lor din lotul de la Ploieşti sunt în mod sigur recoltate din Dacia sau Dobrogea.

Cele mai numeroase exemplare fac parte din tipul de opaiţe cu ciocul cordiform. Alături de cele purtând ştampila, opaiţele acestui tip formează grosul pieselor din colecţia muzeului ploieștean. De altfel, pentru veacurile II-III p. Chr. aceste tipuri sunt majoritare în provinciile imperiului roman.

O lucernă deosebită este cea care poartă ștampila Euctemon, cu mare probabilitate producător care a funcţionat la Tomis. De la Ploieşti avem exemplare din seria care nu poartă ştampilă, dar cu forma şi decorul specifice.

Din zona orientală a imperiului sunt semnalate două opaiţe cu ciocul trapezoidal. Locul lor de origine este Corintul, tipul fiind produs şi la Atena, dar şi la Tomis.

Autorul strânge într-o grupă distinctă exemplarele prevăzute cu mai multe ciocuri.

Un număr de 17 piese autorul consideră că nu pot fi grupate tipologic, fiind vorba de forme hibride sau atipice. Credem totuşi că unele dintre ele (spre exemplu, nr. 
88-91 sau 96, dar nu numai) pot fi socotite variante ale altor tipuri.

Opaiţele romane târzii (secolele IVVII p. Chr.) sunt grupate în patru grupe.

Opaiţele syro-palestiniene, lucemele nord africane şi, în fine, cele mai interesante din punctul nostru de vedere, opaiţele de tip balcanic şi variantele lor locale. Chiar dacă prototipurile lor sunt de origine microasiatică, ele se disting totuşi printr-o mai neglijentă execuţie şi o pastă mai grosieră. Autorul remarcă volumul mare existent în Moesia Secunda şi Schytia Mică pentru veacul al VIlea. Din acest motiv cele mai multe dintre lucerne ploieştene súnt bănuite a fi recoltate din zona de la sud de Dunăre. Un opait medieval încheie seria pieselor de lut.

Lămpile din metal, în general din bronz, dar nu numai, sunt piese de lux, mult mai rar apărute, fortuit sau prin cercetări arheologice. Cele şase piese de la Ploieşti reprezintă un lot mare. Remarcăm piesa nr. 131 descoperită în castrul de la Drajna de Sus, a cărei locaţie şi datare sunt sigure.

Un capitol aparte, mai rar întâlnit în literatura de specialitate îl constituie aşa zisele „falsuri”, obiecte create pentru amatorii de antichităţi, în special în veacul al XIX-lea, piese produse mai cu seamă în Italia şi Egipt.

Dacă în catalogul de la British Museum pentru detectarea lor s-au folosit metode foarte moderne de investigaţie, pentru cele din prezentul volum încadrarea lor se face doar pe bază morfologică.

Chiar dacă lotul nu este unul foarte mare, autorul, în cercetarea sa, a folosit o imensă bibliografie, bibliografie ce ar putea fi o sursă de inspiraţie şi pentru alte studii privind lămpile antice.

Cartea este, aşa cum spuneam de la început, un util catalog, atât în ceea ce priveşte cunoaşterea patrimoniului muzeului prahovean, cât şi $o$ contribuţie privind lucernele antice din România.

Crişan MUŞETEANU 